\title{
Faktor Risiko Determinan Yang Konsisten Berhubungan dengan Kejadian Stunting Pada Anak Usia 6-24 Bulan: Tinjauan Pustaka
}

\section{Consistent Determinant Risk Factors Associated with Stunting in Children Aged 6-24 Months: A Systematic Review}

\author{
Ratnawati $^{{ }^{*}}$, Mohammad Zen Rahfiludin ${ }^{2}$
}

\begin{abstract}
ABSTRAK
Latar Belakang : Stunting masih menjadi masalah kesehatan di dunia dengan prevalensi 21,9\% pada tahun 2018. Ada Banyak variabel faktor risiko stunting yang sudah diteliti. Penelurusan hasil penelitian yang menunjukkan faktor risiko dominan secara konsisten mempergaruhi stunting sangat diperlukan sebagai prioritas untuk pencegahan.

Tujuan : Untuk mengidentifikasi faktor risiko dominan yang secara konsisten bermakna hubungannya dengan kejadian stunting.

Metode : Tinjauan pustaka ini dilakukan dengan mengunakan search engine google scholar dan springerlink E- Journal mengunakan kata stunting usia 6-24 bulan. Kriteria esklusi terbit $>5$ tahun terakhir, jurnal tidak bereputasi pada SCIMAGOJR dan dirujuk < 10 kali dan sinta $>2$.

Hasil Ulasan : Didapatkan 3 artikel jurnal internasional Q1 dan 5 jurnal nasional terakreditasi Sinta 2. Jumlah variabel yang diteliti pada 8 jurnal sebanyak 51 Variabel. Didapatkan 36 variabel yang dilakukan hanya satu kali penelitian dengan hasil yang signifikan berhubungan dengan kejadian stunting sebanyak 16 variabel dan 20 variabel tidak signifikan. Variabel yang dilakukan penelitian dengan hasil analisis yang tidak konsisten sebanyak 8 variabel. Variabel dominan yang menunjukkan hubungan bermakna dengan kejadian stunting secara konsisten dari empat penelitian yang berbeda adalah BBLR dan pendapatan keluarga/indeks kesejahteraan keluarga. Faktor risiko yang terendah\&tertinggi $B B L R(O R=3,26 \& 5,870)$, Pendapatan/Indeks kesejahteraan $(O R=2,2 \& 8,5)$. Tingkat Kecukupan Protein $(O R=5,54 \& 7,65)$ dan usia anak $12-24$ bulan ( $A O R=2,688 \& 3,24)$ konsisten pada 2 penelitian.

Kesimpulan BBLR, pendapatan /indeks kesejahteraan keluarga, tingkat kecukupan protein dan usia anak 12-24 bulan merupakan variabel dengan faktor risiko stunting yang dominan konsisten.
\end{abstract}

Kata Kunci: Stunting, faktor risiko, determinan, konsisten

\section{ABSTRACT}

Background : Stunting remains a global health issue with a prevalence of $21.9 \%$ in 2018 . Many variables of stunting risk factors have been studied. Research results that show dominant risk factors that consistently affect stunting are needed as a priority for prevention.

Objective: To determine the dominant risk factors that are consistently associated with stunting events.

Methods: This systematic review was carried out using the Google Scholar search engine and Springerlink E-Journal using the keyword stunting of children aged 6-24 months. Exclusion criteria were published $>5$ years, journals were not reputable on SCIMAGOJR and were referenced $<10$ times and has a sinta index $>2$.

Results: There were 3 international journal articles $Q 1$ and 5 national journals accredited by Sinta 2 . The number of variables studied in 8 journals is 51 Variables. There were 36 variables that were conducted only one study with significant results related to the incidence of stunting as many as 16 variables and 20 variables were not significant. The variables conducted by the research with inconsistent analysis results were 8 variables. Dominant variables that show a significant relationship with the incidence of stunting consistently from four different studies are low birth weight (LBW) and family income / family welfare index. The lowest \& highest risk factors LBW (OR=3.26 \& 5.870), Income / welfare index (OR=2.2 \& 8.5). Protein Adequacy Level $(O R=5.54 \& 7.65)$ and children aged $12-24$ months ( $A O R=2.688 \& 3.24)$ were consistent in 2 studies. 
Conclusion: LBW, income / family welfare index, level of protein adequacy and children aged 12-24 months were variables with dominant and consistent stunting risk factors.

Keywords: Stunting, risk factors, determinan, consistent

Koresponding :

Ratnawati

*ratnawati@unissula.ac.id

${ }^{1}$ Dosen Fakultas Kedokteran Universitas Islam Sultan Agung, Indonesia

${ }^{2}$ Dosen Fakultas Kesehatan Masyarakat Universitas Diponegoro, indonesia

\section{PENDAHULUAN}

Stunting merupakan panjang atau tinggi balita yang tidak sesuai umurnya menurut standart yang ditetapkan oleh WHO, yaitu lebih dari dua standar deviasi di bawah median ${ }^{1,2,3}$. World Health Organization (WHO) pada tahun 2010 membuat batasan masalah stunting dengan kriteria dianggap mempunyai kasus stunting tinggi bila prevalensi stunting sebesar $30-39 \%$ dan jika $\geq 40 \%$ dikategorikan sebagai kasus stunting yang sangat tinggi ${ }^{4} 5$. Berdasarkan data Kementrian kesehatan rata-rata prevalensi balita stunting di Indonesia pada tahun 20052017 di Indonesia adalah $36,4 \%{ }^{1}$

Menurut UNICEF (2013) factor penyebab stunting disebabkan oleh berbagai factor, faktor keluarga dan rumah tangga (faktor ibu, lingkungan rumah), Perilaku ibu dalam memberikan makanan pendamping (MP) ASI yang tidak adekuat, pemberian ASI dan infeksi. Faktor kontekstual yang berkontribusi terhadap kejadian stunting adalah politik ekonomi, pelayanan kesehatan, pendidikan, sosial budaya, system pertanian dan makanan, dan lingkungan sanitasi air ${ }^{6}$. Penelitian di Ethiopia (2017) prevalensi keseluruhan stunting anak usia 6-59 bulan adalah sebanyak $64,5 \%$. Faktor dominan yang menjadi faktor risiko stunting adalah ibu yang mempunyai pekerjaan sebagai petani $(\mathrm{OR}=1,45$ (1,08- 1.93) dengan $\mathrm{Cl} 95 \%)$, kurangnya suplementasi vitamin-A pascanatal $(A O R=1,54 ;(1,19-$ 2,00) dengan $\mathrm{Cl} 95 \%)$, kategori keluarga miskin ( $\mathrm{AOR}=$ $2,07$; (1,56-2,75) dengan $\mathrm{Cl} 95 \%)$ dan memperoleh makanan keluarga dari hasil pertanian $(A O R=1,44$ (1,09-1,89 dengan Cl 95\%) ${ }^{7}$. Pada tahun 2019 masih penelitian di Etiopia didapatkan hasil kejadian stunting terjadi pada anak berusia antara 24 - 59 bulan berisiko sebesar 7,479 kali menjadi stunting dibandingkan dengan anak yang berusia 0-11 bulan dan usia 12-24 bulan berisiko 5,556 kali menjadi stunting dibandingkan pada anak usia 0-11 bulan, pendapatan keluarga menengah $(O R=0,79(0,399-0,084)$ dengan $\mathrm{Cl} 95 \%)$ dan rumah tangga kaya $(\mathrm{OR}=0,648$ dengan $\mathrm{Cl} 95 \%$ ) merupakan faktor protektif terhadap kejadian stunting. Anak-anak yang tidak diberi ASI memiliki kemungkinan 1.225 kali lebih besar untuk terjadi stunting dibandingkan dengan anak yang ASI esklusif. Anak-anak dari rumah tangga menggunakan internet adalah $56,7 \%$ lebih kecil kemungkinannya untuk terkena stunting ${ }^{8}$.

Faktor risiko dan penelitian stunting yang sudah banyak dilakukan menjadi latar belakang perlu dilakukan review jurnal tentang faktor risiko apa saja yang secara metode penelitian bermakna secara konsisten dari penelitian yang berbeda.

\section{METODE}

Tinjauan pustaka ini dilakukan dengan mengunakan search engine google scholar mengunakan kata kunci "faktor risiko stunting umur 6-24 bulan" dan springer dengan key word "Stunting age 6-24 Month". Pada search engine google sholar artikel yang didapatkan diseleksi berdasarkan Pemilihan artikel dengan menetapkan kriteria inklusi jurnal full text format PDF, jurnal terakreditasi minimal sinta 2. Kriteria esklusi jurnal terbit $>5$ tahun terakhir, dan dikunjungi $<10$ kali, jenis artikel full text format PDF. Pada search engine springerslink E-journal pemilihan artikel berbahasa inggris format PDF full text dengan key word Stunting in Children aged 6-24 Months. Kriteria inklusi jurnal adalah jurnal bereputasi berdasarkan kategori Rangking jurnal SCIMAGOJR bereputasi dan artikel full text format PDF. Kriteria esklusi terbit $>5$ tahun terakhir dan dirujuk $<10$ kali. Metode penelitian artikel merupakan merupakan 
studi analitik observasional dengan pendekatan case control dan cross sectional. Metode pengkajian kualitas artikel mengunakan aplikasi Critical Appraical. Pencarian literature secara sistematik dapat dilihat pada Gambar 1.

\section{HASIL DAN PEMBAHASAN}

Hasil penelusuran artikel mengunakan search engine Google sholar dan Springerlink-E Journal dapat dilihat pada tabel 1.1. Penilaian terhadap variabelvariabel pada penelitian diatas untuk mengetahui konsisten dan tidaknya variabel yang berhubungan pada penelitian yang berbeda dapat dilihat pada tabel 1.2.

Hasil penelusuran artikel didapatkan hasil analisis multivariat pada penelitian di Brebes didapatkan faktor risiko dominan stunting adalah pajanan pestisida, kurangnya asupan energi, protein dan seng ${ }^{9}$. Variabel pajanan pestisida dapat dijadikan pelengkap dari hasil penelitian lainnya karena tidak diteliti pada hasil studi literatur kali ini. Hasil penelitian yang dilakukan di Brebes sesuai dengan hasil penelitian sebelumnya bahwa anak batita dengan asupan energi yang kurang berisiko 2,52 kali terjadi stunting dibandingkan anak dengan asupan energi cukup. Anak batita yang dengan asupan protein kurang berisiko 3,46 kali terjadi stunting dibandingkan anak dengan asupan protein cukup. Kekurangan vitamin B2, B6 dan kekurangan mineral Fe dan Zn pada anak juga memiliki risiko stunting. Pada penelitian ini indikator yang digunakan untuk menilai asupan responden adalah dianggap cukup jika asupan responden memenuhi $80 \%$ dari Angka Kecukupan Gizi $(A K G){ }^{10}$. Jumlah asupan yang diterima anak baik energi, protein, maupun zink dan bertambahnya perkembangan mempunyai perbedaan yang bermakna antara balita stunting dan tidak stunting. Hasil penelitian yang dilakukan di Kelurahan Manyar Surabaya mendapatkan kesimpulan bahwa asupan makanan yang harus diperhatikan adalah sumber protein dan zink yang dapat digunakan sebagai upaya meningkatkan perkembangan otak dan preventif terhadap kejadian stunting $^{11}$. Protein merupakan makronutrien yang berfungsi sebagai reseptor dalam mempengaruhi fungsi DNA yang mengendalikan proses pertumbuhan dengan mengatur sifat dan karakter bahannya ${ }^{12}$.

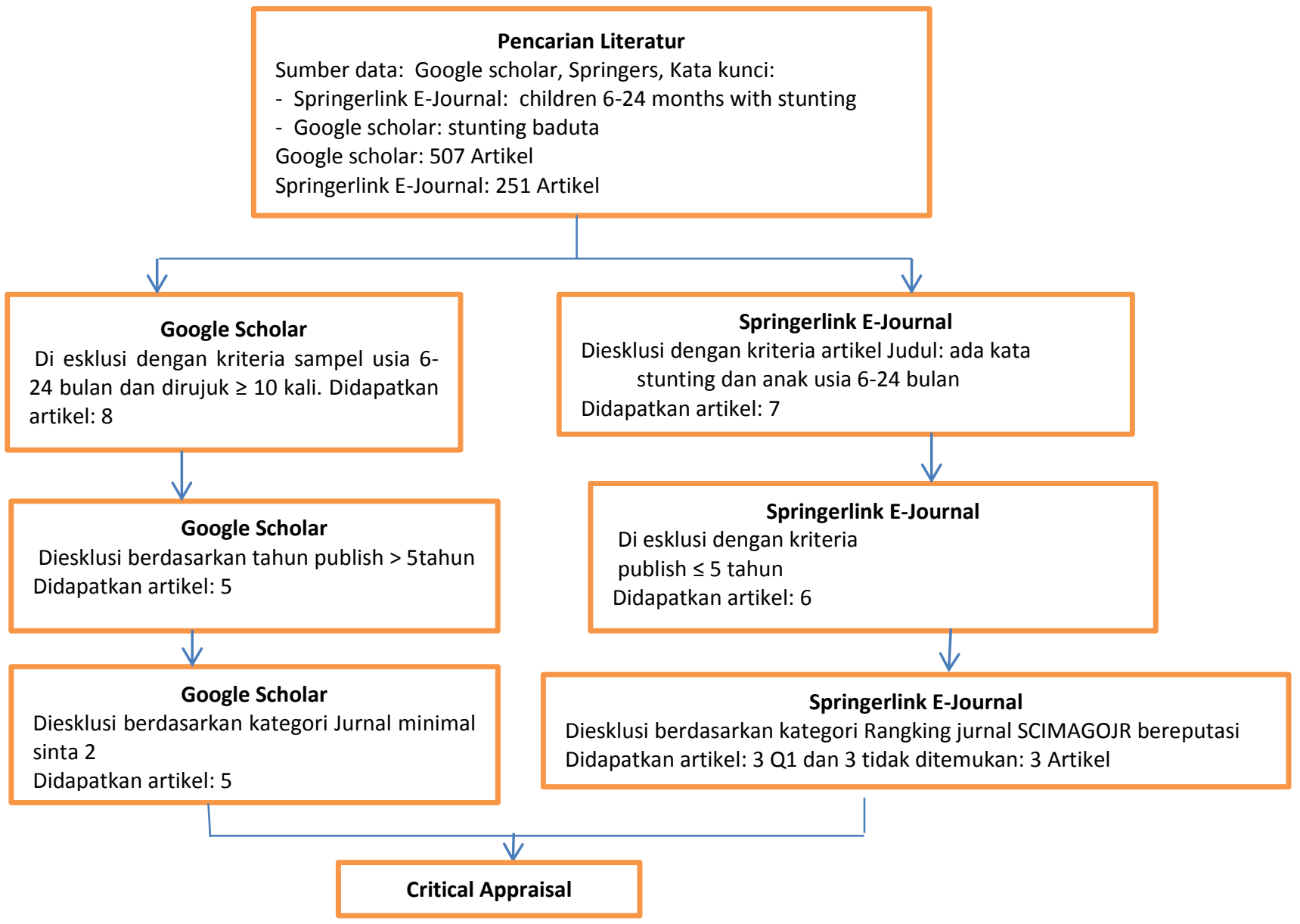

Gambar 1 Bagan Pencarian Literature 
Tabel 1.1 Hasil Penelurusan Faktor Risiko Stunting dari Artikel Jurnal bereputasi dan Terakreditasi Nasional

\begin{tabular}{|c|c|c|c|c|}
\hline $\begin{array}{c}\text { Judul, Penulis dan Identitas } \\
\text { Jurnal }\end{array}$ & $\begin{array}{l}\text { Metode, } \\
\text { Sampel }\end{array}$ & $\begin{array}{l}\text { Hasil dan K } \\
\text { Variabel yang Signifikan }\end{array}$ & $\begin{array}{l}\text { simpulan } \\
\text { Variabel yang } \\
\text { Signifikan }\end{array}$ & Kesimpulan \\
\hline $\begin{array}{l}\text { Stunting, wasting and } \\
\text { associated factors } \\
\text { among children aged 6-24 } \\
\text { months in Dabat health and } \\
\text { demographic surveillance } \\
\text { system site: A community } \\
\text { based crosssectional } \\
\text { study in Ethiopia } \\
\text { Terefe Derso, Amare Tariku } \\
\text {, Gashaw Andargie Biks and } \\
\text { Molla Mesele Wassie } \\
\text { BMC Pediatrics (2017) }\end{array}$ & $\begin{array}{l}\text { - Cross sectional } \\
\text { - Sampel } 587 \text { ibu } \\
\text { dan anak } \\
\text { - } \text { Analisis } \\
\text { Multivariat } \\
\text { - } \text { Tehnik sampling } \\
\text { Random } \\
\text { - } \text { Besar sampel } \\
\text { dihitung } \\
\text { mengunakan } \\
\text { Epi-info } \\
\text { Versi } 3.7 \text { dengan } \\
\text { asumsi } \\
\text { prevalensi } \\
\text { stunting usia 6- } \\
24 \text { bulan 47\% }\end{array}$ & $\begin{array}{l}\text { - } \quad \text { tanpa jamban [AOR = } \\
\text { 1,76; } 95 \% \mathrm{Cl}: 1,17- \\
\text { 2.66] } \\
\text { - } \text { Status kekayaan } \\
\text { miskin [AOR = 2.20; } \\
\text { Cl:1.42- 3.40]. } \\
\text { - } \quad \text { ssia anak 12-24 bulan } \\
\text { AOR = 3.24; CI (2.24- } \\
\text { 4.69) } \\
\text { - Sumplementasi Vit A } \\
\text { ibu pasca natal AOR = } \\
\text { 1.54 (1.02 - 2.33) } \\
\text { - Sumber makanan } \\
\text { AOR= } 1.71 \text { (1.14-2.57) }\end{array}$ & $\begin{array}{l}\text { - Pendidikan ibu } \\
\text { - Pekerjaan ibu } \\
\text { - Pekerjaan ayah } \\
\text { - Banyaknya jenis } \\
\text { variasi makanan } \\
\text { - Sumber air } \\
\text { - Status maritas } \\
\text { - Jumlah keluarga } \\
\text { - Usia ibu } \\
\text { - Jenis Kelamin kepala } \\
\text { rumah tangga } \\
\text { - Riwayat diare } 2 \\
\text { minggu sebelumnya } \\
\text { - IMD } \\
\text { - Vit A maternal } \\
\text { - Pemberian botol < } \\
24 \text { jam } \\
\text { - Waktu pemberian } \\
\text { MP ASI } \\
\text { - Konsumsi Colestrum } \\
\text { - Asi Esklusif }\end{array}$ & 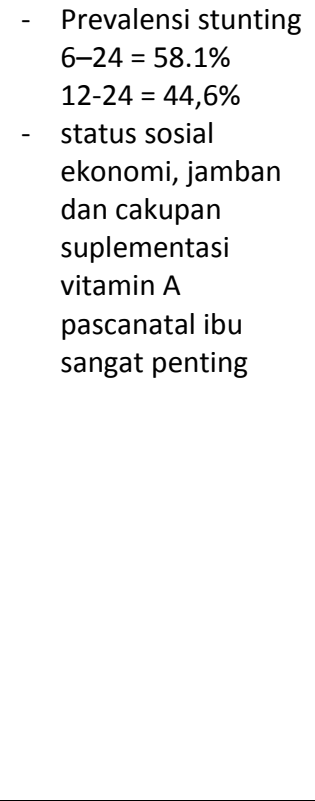 \\
\hline $\begin{array}{l}\text { How well do WHO } \\
\text { complementary feeding } \\
\text { indicators relate to nutritional } \\
\text { status of } \\
\text { children aged 6-23 months in } \\
\text { rural } \\
\text { Northern Ghana? } \\
\text { Mahama Saaka } \\
\text {, Anthony Wemakor, Abdul- } \\
\text { Razak Abizari and Paul Aryee } \\
\text { BMC Public Health (2015) }\end{array}$ & $\begin{array}{l}\text { - Cross sectional } \\
\text { - Tehnik sampling } \\
\text { Cluster } 2 \text { tahap, } \\
\text { proporsional } \\
\text { random } \\
\text { sampling } \\
\text { - Besar sampel } \\
\text { dihirung } \\
\text { mengunakan Epi } \\
\text { software for } \\
\text { epidemiologic } \\
\text { statistics version } \\
\text { 3.01. }\end{array}$ & $\begin{array}{l}\text { - Varaisi makanan <4 } \\
\text { macam }(p=0,05) \\
\text { - Waktu pemberian MP } \\
\text { ASI }(p=0,002) \\
\text { - Pemberian makanan } \\
\text { pendamping yang } \\
\text { sesuai }(p=0,0012) \\
\text { - Pendidikan ibu } \\
\text { ( } p=0,004) \\
\text { - Infeksi diare } \\
\text { - Jenis kelamin anak } \\
\text { (0,001) } \\
\text { - Indeks Kekayaan } \\
\text { ( } p=0,001) \\
\text { - Umur anak ( } p=0,001) \\
\text { - Agama }(p=0,038) \\
\text { - ANC }(p=0,003)\end{array}$ & $\begin{array}{l}\text { - Waktu MP ASI } 6 \\
\text { bulan } \\
\text { - Mengunakan botol } \\
\text { susu } \\
\text { - Minimal konsumsi } \\
\text { daging } \\
\text { - Makanan minimal } \\
\text { yang dapat diterima } \\
\text { - Komposisi iodium } \\
\text { dalam garam) }\end{array}$ & $\begin{array}{l}\text { Determinan regresi } \\
\text { logistic: } \\
\text { - } \text { Konstanta }-12.353 \\
\text { - } \text { Skor pemberian } \\
\text { makanan } \\
\text { pendamping yang } \\
\text { sesuai konstanta } 0,04 \\
\text { ( } p=0,05 \text { ) } \\
\text { - Pendidikan ibu } \\
\text { konstansta } 0,008 \\
\text { ( } p=0,001 \text { ) } \\
\text { - Infeksi Diare } 0,1 \\
\text { ( } p=0,001 \text { ) } \\
\text { - Jenis Kelamin } 0,03 \\
\text { ( } p=0.005 \text { ) }\end{array}$ \\
\hline $\begin{array}{l}\text { Minimum dietary diversity and } \\
\text { associated } \\
\text { factors among children aged } \\
\text { 6-23 months } \\
\text { in Addis Ababa, Ethiopia } \\
\text { Dagmawit Solomon } \\
\text {, Zewdie Aderaw } \\
\text { and Teketo Kassaw Tegegne } \\
\text { BMC Internasional Journal for } \\
\text { Equity in health (2017) }\end{array}$ & $\begin{array}{l}\text { - } \text { cross sectional } \\
\text { - Jumlah sampel } \\
352 \\
\text { - } \text { Tehnik sampling } \\
\text { Random } \\
\text { - Analisis } \\
\text { multivariat }\end{array}$ & $\begin{array}{ll}\text { - } & \text { Pendidikan ibu } \\
& \text { sedang } \mathrm{p}<0,001 ; \text { AOR } \\
& 4.62 \text { (2.31-9.25) } \\
\text { - } & \text { Pendidikan ibu tinggi } \\
\text { p<0,01; AOR 4.49 } & (1.50-13.42) \\
\text { - } \quad \text { Keanekaragaman } \\
\text { makanan AOR } 1.98 \\
\text { (1.11-3.53) } \\
\text { Pendapatan level } 3 \\
\text { p<0,01 AOR 4.13 } \\
\text { (1.80-9.50) } \\
\text { Pendapatan level } 4 \mathrm{p}< \\
\text { 0,001 AOR 4.13 } \\
\text { (1.80-9.50) }\end{array}$ & $\begin{array}{l}\text { - Usia ibu } \\
\text { - Pekerjaan ibu } \\
\text { - Pendidikan ayah } \\
\text { - Pekerjaan ayah }\end{array}$ & $\begin{array}{l}\text { Keragaman makanan } \\
\text { tinggi factor dominan }\end{array}$ \\
\hline $\begin{array}{l}\text { Faktor risiko stunting pada } \\
\text { anak umur 6-24 bulan di } \\
\text { kecamatan } \\
\text { Penanggalan kota }\end{array}$ & $\begin{array}{l}\text { - } \text { Case control } \\
\text { - Sampel } 110 \text { (55 } \\
\text { kasus dan } 55 \\
\text { kontrol) }\end{array}$ & $\begin{array}{ll}- & \text { Pekerjaan ayah OR } \\
& 2,01(1,67-2,44) \\
- & \text { Pendapatan OR=8,5 } \\
& (95 \% \mathrm{Cl}: 2,68-26,89),\end{array}$ & $\begin{array}{l}\text { - } \text { Ketersediaan } \\
\text { Sumber air bersih } \\
\text { - Pendidikan ibu } \\
\text { - Pekerjaan ibu }\end{array}$ & $\begin{array}{l}\text { - } \text { Perawakan pendek } \\
\text { orang tua sebagai } \\
\text { faktor risiko paling } \\
\text { dominan terhadap }\end{array}$ \\
\hline
\end{tabular}




\begin{tabular}{|c|c|c|c|c|}
\hline $\begin{array}{l}\text { Subulussalam provinsi Aceh } \\
\text { Wanda Lestari, Ani Margawati, } \\
\text { M. Zen Rahfiludin } \\
\text { Jurnal Gizi Indonesia (ISSN : } \\
\text { 1858-4942) }\end{array}$ & $\begin{array}{l}\text { - Tehnik sampling } \\
\text { konsekutif } \\
\text { sampling }\end{array}$ & 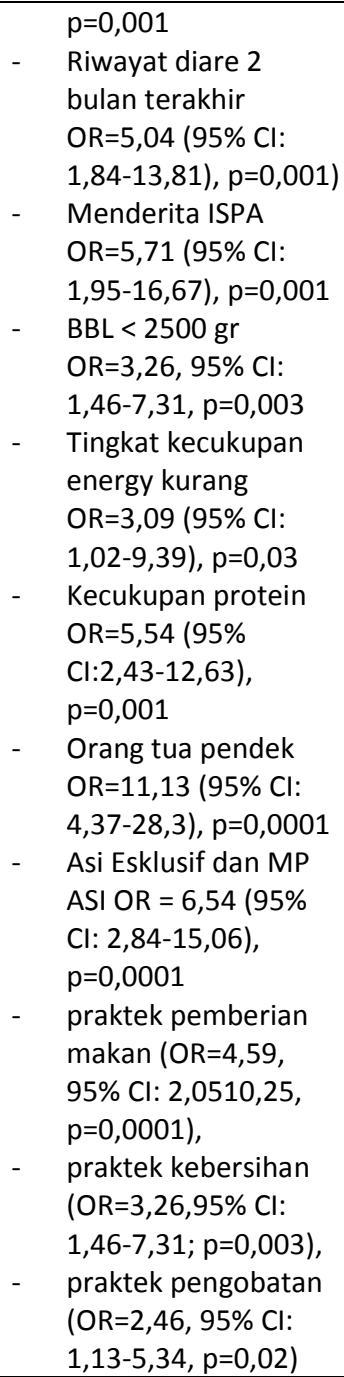 & - Pendidikan ayah & $\begin{array}{ll}\text { stunting Konstanta } \\
13,16 \\
\text { - } \\
\text { Tidak ASI eksklusif } \\
\text { Konstanta 3,02 OR } \\
\text { 0,068 }(0,92-9,93) \\
\text { - } & \text { Frekuensi Diare } \\
& \text { Konstanta 6,33 OR } \\
& 0,016(1,40-28,62) \\
\text { - } & \text { Frekuensi ISPA } \\
& \text { Konstanta 8,99 OR } \\
\text { 0,005 }(1,94-41,51) \\
\text { - } \text { TKP rendah } \\
\text { Konstanta 5,87 OR } \\
\text { 0,005 (1,70-20,20) } \\
\text { - Pengeluaran } \\
\text { keluarga yang } \\
\text { rendah Konstanta } \\
\text { 6,11 OR 0,017 (1,39- } \\
\text { 26,90) }\end{array}$ \\
\hline $\begin{array}{l}\text { Faktor Risiko Stunting pada } \\
\text { Anak Usia 6-23 Bulan di } \\
\text { Kabupaten } \\
\text { Jeneponto } \\
\text { Fahmi Hafid, Nasrul } \\
\text { Indonesian Journal of Human } \\
\text { Nutrition } \\
\text { Diterima: / Direview: / Dimuat: } \\
\text { April 2016/ April 2016/ Juli } \\
2016^{32}\end{array}$ & $\begin{array}{ll}\text { - } & \text { Cross sectional } \\
\text { - } & \text { Sampel } 350 \\
\text { - } & \text { Tehnic } \\
& \text { sampling } \\
& \text { xhaustive } \\
& \text { sampling } \\
\text { - } & \text { Analisis } \\
& \text { Multivariat } \\
& \text { regresi logistic }\end{array}$ & 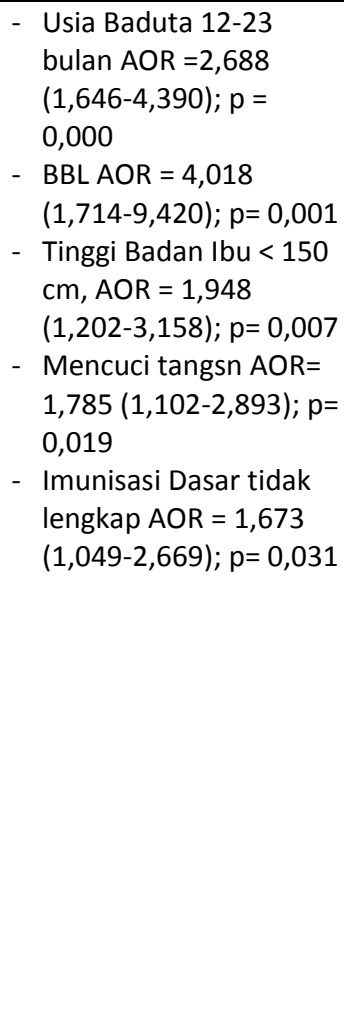 & $\begin{array}{ll}\text { - } & \text { Asupan snack } \\
\text { - } & \text { Asupan mie } \\
& \text { instant } \\
\text { - } & \text { Asupan MP-ASI } \\
\text { - } & \text { Sumber Air } \\
\text { - } & \text { Jenis kelamin anak } \\
\text { - } & \text { Jarak kelahiran } \\
\text { - } & \text { Kategori usia ibu } \\
\text { - } & \text { Paparan rokok }\end{array}$ & 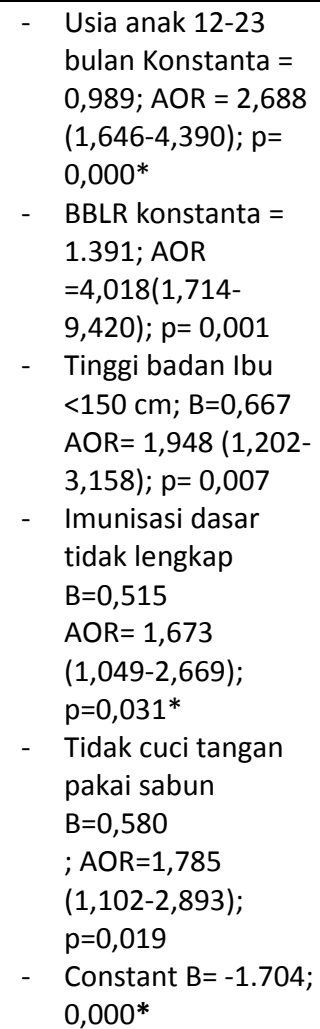 \\
\hline
\end{tabular}




\begin{tabular}{|c|c|c|c|c|c|}
\hline $\begin{array}{l}\text { Waktu pemberian makanan } \\
\text { pendamping ASI (MP-ASI) } \\
\text { berhubungan dengan kejadian } \\
\text { stunting anak usia 6-23 } \\
\text { bulan di Kecamatan Sedayu } \\
\text { Dwi Puji Khasanah, Hamam } \\
\text { Hadi, Bunga Astria } \\
\text { Paramashanti } \\
\text { 1JURNAL GIZI DAN DIETETIK } \\
\text { INDONESIA } \\
\text { Vol. 4, No. 2, Mei 2016: 105- } \\
111^{33}\end{array}$ & $\begin{array}{l}\text { - } \text { Cross sectional } \\
\text { - Jumalh sampel } \\
190 \\
\text { - } \text { Tehnik sampling } \\
\text { probability } \\
\text { proporsional to } \\
\text { size }\end{array}$ & - & $\begin{array}{l}\text { Waktu pemberian MP } \\
\text { ASI tidak sesuai OR } \\
=2,867(1,453-5,656) \\
p=0,002\end{array}$ & -Asupan energi & $\begin{array}{l}\text { Waktu pemberian } \\
\text { makanan MP ASI } \\
\text { merupakan resiko yang } \\
\text { berhubungan dengan } \\
\text { stunting }\end{array}$ \\
\hline $\begin{array}{l}\text { Riwayat Berat Badan Lahir } \\
\text { dengan Kejadian Stunting } \\
\text { pada Anak Usia Bawah Dua } \\
\text { Tahun } \\
\text { Atikah Rahayu*, Fahrini } \\
\text { Yulidasari**, Andini Octaviana } \\
\text { Putri**, Fauzie Rahman** } \\
\text { Kesmas: Jurnal Kesehatan } \\
\text { Masyarakat Nasional Vol. 10, } \\
\text { No. 2, November } 2015^{13}\end{array}$ & $\begin{array}{l}\text { - } \text { Cross sectional } \\
\text { - } \text { Populasi ibu-ibu } \\
\text { yang } \\
\text { memiliki anak } \\
\text { baduta } \\
\text { - } \text { besar sampel } \\
\text { sejumlah } 117 \\
\text { terdiri dari anak } \\
\text { baduta } \\
\text { - Analisa } \\
\text { Chusquare dan } \\
\text { Multivariat } \\
\text { regresi logistik }\end{array}$ & - & $\begin{array}{l}\text { Riwayat status BBLR, } \\
\text { OR = 5,870 }(1,26- \\
29,61) ; p=0,015\end{array}$ & $\begin{array}{ll}\text { - } & \text { Pekerjaan ibu } \\
\text { - } & \text { Tinggi badan ayah } \\
\text { - } & \text { Tinggi badan ibu }\end{array}$ & $\begin{array}{l}\text { Riwayat } B B L R B=1,862 ; \\
p= \\
0,022 ; O R=1,555 \\
(0,032-0,762)\end{array}$ \\
\hline $\begin{array}{l}\text { Faktor risiko stunting pada } \\
\text { anak umur } 12-24 \text { bulan } \\
\text { Wiwien Fitrie Wellina } \\
\text {, Martha I. Kartasurya } \\
\text {, M. Zen Rahfilludin } \\
\text { Jurnal Gizi Indonesia (ISSN: } \\
\text { 1858-4942) } \\
\text { Vol. 5, No. 1, Desember } 2016 \text { : } \\
55-61^{9}\end{array}$ & $\begin{array}{l}\text { - } \text { Case control } \\
\text { - } \\
\text { Sampel } 154 \text { (77 } \\
\text { kasus dan } 77 \\
\text { kontrol) }\end{array}$ & - & $\begin{array}{l}\text { Energi kurang OR 7,71 } \\
(3,63-16,3) ; p=0,001 \\
\text { Protein kuran OR 7,65 } \\
(3,67-15,9) ; p=0,001 \\
\text { Zeng kurang OR =8,78 } \\
(3,58-21,5) ; p=0,001 \\
\text { BBLR OR =3,63 (1,65- } \\
\text { 7,96); } p=0,002 \\
\text { Panjang lahir OR = } \\
\text { 6,29 (3,12-12,6); } p= \\
\text { 0,00 } \\
\text { Pajanan pestisida } \\
\text { sering OR }=8,48(3,93- \\
\text { 18,28); } p=0,001\end{array}$ & $\begin{array}{ll}\text { - } & \text { Vitamin A kurang } \\
\text { - } & \text { Frekwensi diare } \\
\text { - } & \text { Frekwensi ISPA OR } \\
& =2,105(0,93-4,76) \\
& \text { p }=0,05\end{array}$ & $\begin{array}{l}\text { Faktor risiko dominan } \\
\text { adalah tingkat } \\
\text { kecukupan energy, } \\
\text { tingkat kecukupan } \\
\text { protein dan pajanan } \\
\text { pestisida Merupakan } \\
\text { Faktor Risiko Dominan }\end{array}$ \\
\hline
\end{tabular}

Pada penelitian yang dilakukan di Kabupaten Hulu Sungai Utara tepatnya Puskesmas Sungai Karias didapatkan hasil riwayat BBLR menjadi faktor risiko dominan kejadian stunting ${ }^{13}$. Berat Bayi Lahir Rendah (BBLR) merupakan variabel yang berhubungan secara konsisten dengan stunting pada 4 artikel penelitian review jurnal ini. Hasil studi literatur ini juga menunjukkan hasil yang sama dengan penelitian di Sedayu Yogyakarta, dengan hasil riwayat berat badan lahir $\geq 2.500$ gram menjadi faktor protektif terhadap terjadinya anak stunting sebesar $0,8 \mathrm{kali}^{14}$. Hasil analisis multivariat penelitian yang dilakukan di Sumatera didapatkan berat lahir rendah berisiko 1,71 kali terjadi stunting dibandingkan dengan balita yang mempunyai riwayat berat lahir normal ${ }^{15}$. Berat badan lahir merupakan gambaran kondisi kronis selama didalam kandungan, merupakan gambaran perilaku ibu melakukan asupan makanan dan kondisi kesehatan ibu selama hamil. Pemerintah telah melakukan kegiatan intervensi spesifik pada ibu hamil dengan program pemberian besi, folat, makanan tambahan terhadap ibu hamil dengan masalah Kekurangan Energi yang Kronik (KEK), penanganan kecacingan, suplementasi kalsium, pembagian kelambu dan ibu hamil yang didiagnosis malaria dilakukan pengobatan ${ }^{16}$.

Indeks kesejahteraan atau pendapatan juga merupakan variabel yang konsisiten dalam 4 penelitian yang berbeda menunjukkan hubungan signifikan. Hasil studi literature ini sesuai dengan hasil penelitian di Aceh yang menyatakan terdapat hubungan yang signifikan antara penghasilan orang tua dengan status gizi. Status gizi sangat dipengaruhi oleh sosial ekonomi orang tua. Status gizi (stunting) juga relatif dipengaruhi oleh perbedaan sosial ekonomi yang mengunakan standar pendapatan per kapita atau pendapatan rumah tangga berbasis aset ${ }^{17}$. Pada penelitian di wilayah Puskesmas Kedung Banteng Banyumas didapatkan hasil bahwa sebanyak 93\% jumlah dan kualitas pangan keluarga kurang disebabkan tidak memiliki uang yang cukup untuk mendapatkan makanan sehingga hanya mendapatkan pangan dari hasil pertanian dan kebun yang ada ${ }^{18}$.

Permasalahan gizi terutama stunting prevalensi tertinggi terjadi pada usia dua tahun ${ }^{11}$. Usia 12-24 bulan merupakan variabel yang konsisiten berhubungan signifikan dengan stunting pada 2 hasil 
penelitian studi literatur. Hasil studi literatur ini tidak sejalan dengan penelitian yang dilakukan di Desa Kembangan, Kecamata Kebomas, Kabupaten Gresik yang menunjukkan hasil bahwa prevalensi tertinggi kejadian stunting pada kelompok usia 25-36 bulan, sedangkan prevalensi tertinggi anak normal pada usia 12-24 bulan $^{19}$. Usia anak pada 1000 hari pertama kehidupan
(HPK), sering disebut Golden Age. Golden Age ini dihitung mulai dari pembuahan sampai dengan umur 2 tahun, masa ini tumbuh-kembang anak pesat. Pada Usia 2 tahun, anak mencapai tinggi badan (TB) setengah dari TB orang dewasa, volume otak $90 \%$ volume otak dewasa, perkembangan otaknya mencapai $80 \%$ otak dewasa $^{20}$.

Tabel 1.2 Tabel Rangkuman Variabel yang Signifikan Berhubungan dengan Stunting

\begin{tabular}{|c|c|c|c|}
\hline Variabel & $\begin{array}{l}\text { Frekuensi } \\
\text { diteliti }\end{array}$ & $\begin{array}{l}\text { Frekuensi } \\
\text { signifikan }\end{array}$ & Hasil Signifikan \\
\hline BBLR & 4 & 4 & $\begin{array}{l}\text { OR=3,26, 95\% Cl: } 1,46-7,31, p=0,003 \\
\text { OR = 5,870 (1,26-29,61); } p=0,015 \\
\text { OR 3,63 }(1,65-7,96) ; p=0,002 \\
\text { AOR = 4,018 }(1,714-9,420) ; p=0,001\end{array}$ \\
\hline Pendapatan & 4 & 4 & $\begin{array}{cc}- & \text { Pendapatan level } 3 \mathrm{p}<0,01 \mathrm{AOR} 4.13(1.80-9.50) \\
\text { - } & \text { Pendapatan level } 4 \mathrm{p}<0,001 \text { AOR } 4.13(1.80-9.50) \\
\text { - } & \text { Status kekayaan miskin [AOR = 2.20; Cl:1.42- 3.40]. } \\
\text { - } & \text { Indeks Kekayaan ( } \mathrm{p}=0,001) \\
\text { - } & \text { Pendapatan OR=8,5 (95\% Cl: } 2,68-26,89), \mathrm{p}=0,001\end{array}$ \\
\hline $\begin{array}{l}\text { Usia Baduta } 12-23 \\
\text { bulan }\end{array}$ & 2 & 2 & $\begin{array}{l}\mathrm{AOR}=2,688(1,646-4,390) ; p=0,000 \\
\mathrm{AOR}=3.24 ; \mathrm{Cl}(2.24-4.69)\end{array}$ \\
\hline Asupan Protein & 2 & 2 & $\begin{array}{lc} & \text { Protein kuran OR } 7,65(3,67-15,9) ; p=0,001 \\
- & \text { Kecukupan protein OR=5,54 }(95 \% \mathrm{Cl}: 2,43-12,63) \\
\mathrm{p}=0,001\end{array}$ \\
\hline Asupan Energi & 3 & 2 & $\begin{array}{l}\text { - } \quad \text { Energi kurang OR } 7,71(3,63-16,3) ; p=0,001 \\
-\quad \text { Tingkat kecukupan energy kurang OR=3,09 }(95 \% \mathrm{CI}: \\
1,02-9,39), p=0,03\end{array}$ \\
\hline $\begin{array}{l}\text { Waktu pemberian MP } \\
\text { ASI tidak sesuai }\end{array}$ & 3 & 2 & $O R=2,867(1,453-5,656) ; p=0,002$ \\
\hline $\begin{array}{l}\text { Keanekaragaman } \\
\text { makanan }\end{array}$ & 3 & 2 & $\begin{array}{l}\text { AOR } 1.98(1.11-3.53 \\
\text { P }(0,05)\end{array}$ \\
\hline $\begin{array}{l}\text { Riwayat diare } 2 \text { bulan } \\
\text { terakhir }\end{array}$ & 4 & 2 & $\mathrm{OR}=5,04(95 \% \mathrm{Cl}: 1,84-13,81), \mathrm{p}=0,001)$ \\
\hline Asi Esklusif & 2 & 1 & \\
\hline Jenis Kelamin & 2 & 1 & $P(0,000)$ \\
\hline Tinggi Badan Ibu & 2 & 1 & $<150 \mathrm{~cm}, \mathrm{AOR}=1,948(1,202-3,158) ; p=0,007$ \\
\hline $\begin{array}{l}\text { Pemberian makanan } \\
\text { pendamping yang } \\
\text { sesuai }\end{array}$ & 1 & 1 & $p=0,0012)$ \\
\hline
\end{tabular}

\begin{tabular}{|c|c|c|c|}
\hline Panjang lahir & 1 & 1 & $O R=6,29(3,12-12,6) ; p=0,00$ \\
\hline Praktek kebersihan & 1 & 1 & $(\mathrm{OR}=3,26,95 \% \mathrm{Cl}: 1,46-7,31 ; \mathrm{p}=0,003)$ \\
\hline $\begin{array}{l}\text { Praktek pemberian } \\
\text { makanan }\end{array}$ & 1 & 1 & (OR=4,59, 95\% Cl: 2,0510,25, p=0,0001), \\
\hline praktek pengobatan & 1 & 1 & $(\mathrm{OR}=2,46,95 \% \mathrm{Cl}: 1,13-5,34, \mathrm{p}=0,02)$ \\
\hline Menderita ISPA & 1 & 1 & $\mathrm{OR}=5,71(95 \% \mathrm{Cl}: 1,95-16,67), \mathrm{p}=0,001$ \\
\hline Pekerjaan ayah & 3 & 1 & Pekerjaan ayah OR $2,01(1,67-2,44)$ \\
\hline Pendidikan Ibu & 4 & 1 & $\begin{array}{l}\text { Pendidikan ibu sedang } p<0,001 ; \text { AOR } 4.62(2.31-9.25) \\
\text { Pendidikan ibu tinggi } p<0,01 ; \text { AOR } 4.49 \text { (1.50-13.42) }\end{array}$ \\
\hline
\end{tabular}

Pajanan pestisida sebagai faktor risiko dominan pada penelitian di Brebes ini juga sesuai dengan hasil penelitian di Magelang, pekerjaan yang berkaitan pestisida berhubungan dengan kejadian BBLR $(p=0,0001)^{21}$. Hasil penelitian yang dilakukan di wilayah puskesmas Sawangan 1 didapatkan bahwa ibu yang terpapar pestisida dalam pekerjaan pertanian yang terdiri dari 3 variabel, yaitu mencampur pestisida $(p=$ $0,022 ; \mathrm{OR}=2,670 ; \mathrm{Cl} 95 \%=1,141-6,247)$, menyemprot $(p=0,021 ; O R=4,400 ; C l 95 \%=1,148-16,868$ dan mencuci alat penyemprot pestisida $(p=0,021 ; O R=$ $4,400 ; \mathrm{Cl} 95 \%=1,148-16,868)$. Ketiga variabel paparan 
pestisida ini semuanya menunjukkan hubungan yang bermakna dengan kejadian stunting ${ }^{21}$. Paparan pestisida memberikan dampak potensi bahaya kesehatan pada masyarakat yang domisili di lingkungan pertanian. Masyarakat secara umum yang didalamnya ada anak yang tinggal di lingkungan pertanian, berisiko kontak dengan pestisida secara tidak langsung melalui paparan residu dari lingkungan, bisa berasal dari hasil panen, air dan tanah ${ }^{22}$. Mekanisme terjadinya kejadian stunting akibat paparan pestisida menyebabakan terjadinya gangguan jalur sintesis dan metabolisme hormone tiroid melaui 4 jalur. Jalur gangguan pertama karena pestisida menempati reseptor TSH (TSH-r) pada kelenjar tiroid sehingga TSH tidak bisa masuk kedalam kelenjar tiroid sehingga sintesis hormone tiroid terganggu ${ }^{23}$. Jalur yang ke dua melalui mekanisme kerja enzim deyodinase tipe 1 (D1) yang bekerja mengkatalis T4 berubah menjadi T3 24. Jalur gangguan yang ketiga karena struktur kimia pestisida hampir sama dengan hormon tiroid sehingga menyebabkan terjadinya kompetisi pengikatan oleh reseptor hormon tiroid (TH-r) pada sel target ${ }^{23}$. Jalur yang keempat, ada dugaan pestisida memacu kerja enzim D3 sehingga T4 dirubah menjadi rT3 (hormone tiroid menjadi inaktif) sehingga bentuk aktif (T3) dalam tubuh kurang ${ }^{23,25}$. Adanya gangguan sintesis dan metabolism hormone tyroid menyebabkan orang akan mengalami hipotiroid. Hormon tyroid sendiri berfungsi untuk proses metabolisme tubuh, pertumbuhan fisik dan perkembangan mental.

Tabel 1.3 Variabel Yang Tidak Signifikan Berhubungan dengan Kejadian Stunting

\begin{tabular}{ll}
\hline \multicolumn{1}{c}{ Variabel } & $\begin{array}{l}\text { Frekuensi } \\
\text { Penelitian }\end{array}$ \\
\hline Pekerjaan Ibu & 4 \\
\hline Usia Ibu & 3 \\
\hline Minimal konsumsi daging & 1 \\
Mengunakan botol susu & 1 \\
Makanan minimal yang & 1 \\
dapat diterima & \\
Konsumsi kolustrum & 1 \\
Komposisi yodium dalam & 1 \\
garam & \\
Jumlah keluarga & 1 \\
Jenis Kelamin kepala rumah & 1 \\
tangga & \\
Pemberian botol <24 jam & 1 \\
Status marital & 1 \\
Jarak kelahiran & 1 \\
Paparan rokok & 1 \\
Sumber Air & 1 \\
Vitamin A kurang & 1 \\
IMD & 1 \\
Tinggi Badan Ayah & 1 \\
Asupan Snack & 1 \\
Asupan Mie Instan & 1 \\
Asupan MP-Asi & 1 \\
\hline
\end{tabular}

Infeksi diare merupakan variabel faktor dominan pada 2 review artikel jurnal ini yang berhubungan dengan stunting, yaitu penelitian di Ethiopia ${ }^{26}$ dan Ghana ${ }^{27}$. Pnelitian yang dilakukan di
Ethiopia menunjukkan variabel yang dominan berhubungan dengan kejadian stunting yaitu rumah tanpa jamban merupakan ${ }^{26}$. Hasil studi literatur ini sejalan dengan hasil penelitian di Kedung Banteng di Banyumas bahwa kejadian stunting pada batita yang memilki sanitasi lingkungan rumah kurang baik berisiko lebih besar dibandingkan dengan batita yang memiliki sanitasi rumah baik. Hal ini terjadi karena rumah batita yang memenuhi syarat rumah sehat masih rendah, tidak ada tempat pembuangan sampah tertutup dan kedap air, ventilasi dan pencahayaan kurang, , belum mempunyai akses jamban keluarga dan status ekonomi keluarga masih relatif rendah ${ }^{18}$. Penelitian yang dilakukan oleh departemen kesehatan anak Universitas Virginia USA melaporkan model tikus cryptosporidiosis yang disapih (sebagai model gambaran anak yang putus dari pemberian ASI dari ibunya). Penyapihan pada tikus ini menyebabkan perubahan diet sehingga terjadi mudah terjadi malnutrisi, penurunan berat badan, tinja yang dikeluarkan lebih banyak, dan beban jaringan parasit di ileum dan usus besar secara signifikan lebih tinggi pada tikus yang mengandung ookista, model ini sangat mirip dengan manusia yang rentan populasi anak-anak setelah disapih ${ }^{28}$.

Variabel yang berkaitan dengan MP - ASI muncul konsisten 2 kali sebagai faktor dominan kejadian stunting pada penelitian di Ethiopia dan Kecamatan Sedayu tetapi tidak menjadi faktor risiko pada penelitian di Aceh. Hasil studi literatur ini sejalan dengan hasil penelitian di Surabaya tepatnya di puskesmas Sidotopo bahwa ada terdapat hubungan riwayat ibu dalam memberikan MP-ASI dengan Persepsi Perilaku Picky Eater balita umur 12-36 Bulan. Picky Eater merupakan perilaku anak yang terlalu pemilih terhadap makanan, balita cenderung mempunyai preferensi makanan kuat, variasi jenis makanan kurang, terbatas jenis tertentu saja dalam memilih makanan dan terhadap makanan yang baru sulit mencoba ${ }^{29}$.

\section{KESIMPULAN}

Hasil systematic review factor risiko stunting yang secara konsisten menjadi faktor penentu stunting pada review jurnal ini adalah BBLR, pendapatan /indeks kesejahteraan keluarga, tingkat kecukupan protein dan usia anak 12-24 bulan. Hasil studi literature ini menyimpulkan bahwa BBLR, pendapatan tingkat kecukupan protein merupakan variabel yang terkait dengan asupan makanan. Pendapatan yang tinggi memberikan akses makanan yang bagus sehingga BBLR tidak terjadi dan kebutuhan protein terpenuhi terutama pada usia 12-24 bulan.

\section{ACKNOWLEDGEMENT}

Penulis mengucapkan terimakasih kepada para Dosen Program Studi Doktoral Fakultas Kesehatan Masyarakat UNDIP yang telah membimbing dalam pembuatan artikel ini.

\section{REFERENSI}

1. Kementerian Kesehatan Republik Indonesia. Situasi Balita Pendek (Stunting) di Indonesia. (Kementrian Kesehatan RI, 2018). 
2. WHO. Stunting in a nutshell. (2019).

3. kementerian Kesehatan Republik Indonesia. Standar Antropometri Penilaian Status Gizi Anak. (2011).

4. Onfs, M. De, Monteiro, C., Akre, J. \& Clugston, $\mathrm{G}$. The worldwide magnitude of protein-energy malnutrition : an overview from the WHO Global Database on Child Growth. 71, 703-712 (1993).

5. Onis, M. De et al. Prevalence thresholds for wasting, overweight and stunting in children under 5 years Public Health Nutrition. 1-5 (2018). doi:10.1017/S1368980018002434

6. WHO-conceptual-framework-on-ChildhoodStunting-Context-Causes-and-Consequences.

7. Tariku, A., Biks, G. A., Derso, T., Wassie, M. M. \& Abebe, S. M. Stunting and its determinant factors among children aged $6-59$ months in Ethiopia. 1-9 (2017). doi:10.1186/s13052-0170433-1

8. Angdembe, M. R., Dulal, B. P., Bhattarai, K. \& Karn, S. Trends and predictors of inequality in childhood stunting in Nepal from 1996 to 2016. 1-17 (2019).

9. Wellina, W. F., Kartasurya, M. I. \& Rahfilludin, M. Z. Faktor risiko stunting pada anak umur 1224 bulan. 5, 55-61 (2016)

10. Hidayati, L., Hadi, H. \& Kumara, A. Kekuranagn Energi dan Zat Gizi Merupakan Faktor Risiko Kejadian Stunted Pada Anak Usia 1-3 Tahun. 89-104

11. Adani, F. Y. \& Nindya, T. S. Perbedaan Asupan Energi, Protein , Zink, dan Perkembangan pada Balita Stunting dan non Stunting The Differences of Energy, Protein , Zinc Intake and Development to Stunting and non-Stunting Toddler. Amerta Nutr. 46-51 (2017). doi:10.20473/amnt.v1.i2.2017.46-51

12. Budiyanto. Dasar Dasar Ilmu Gizi. (Universitas Muhammadiyah Malang Press, 2004).

13. Atikah Rahayu, Fahrini Yulidasari, Andini Octaviana Putri, F. R. Riwayat Berat Badan Lahir dengan Kejadian Stunting pada Anak Usia Bawah Dua Tahun Birth Weight Records with Stunting Incidence among Children under Two. 67-73 (2015).

14. Masrin, M., Paratmanitya, Y. \& Aprilia, V. Ketahanan pangan rumah tangga berhubungan dengan stunting pada anak usia 6-23 bulan. J. Gizi dan Diet. Indones. (Indonesian J. Nutr. Diet. 2, 103 (2016).

15. Fitri. Berat Lahir Sebagai Faktor Dominan Terjadinya Stunting Pada Balita (12-59 Bulan) Di Sumatra. Kesehatan Masyarakat Fakultas Kesehatan Masyarakat Universitas Indonesia (Universitas Indonesia, 2012).

16. Kementerian PPN/ Bappenas. Rencana Aksi Nasional dalam Rangka Penurunan Stunting: Rembuk Stunting. Rencana Aksi Nas. dalam Rangka Penurunan Stunting Rembuk Stunting 1-51 (2018).

17. Aramico, B., Sudargo, T. \& Susilo, J. Hubungan sosial ekonomi, pola asuh, pola makan dengan stunting pada siswa sekolah dasar di Kecamatan Lut Tawar, Kabupaten Aceh Tengah. J. Gizi dan Diet. Indones. (Indonesian J. Nutr. Diet. 1, 121 (2016).

18. Kusumawati, E., Rahardjo, S. \& Sari, H. P. Mode Pengendalian Faktor Risiko Stunting pada Anak Usia di Bawah Tiga Tahun. J. Kesehat. Masy. 9, 249-256 (2013).

19. Welasasih, Bayu Dwi, R. B. W. Beberapa Faktor Yang Berhubungan Dengan Status Gizi Balita Stunting. Indones. J. Public Heal. 8, 99-104 (2012).

20. Patria, S. Y. Gizi Anak pada Masa Emas ( golden age ). (2017). Available at:

http://fk.ugm.ac.id/wpcontent/uploads/2017/09/Gizi-Anak-GoldenAge.pdf.

21. Annisa Aulia Nurrohmah, Nurjazuli, T. J. Hubungan Riwayat Paparan Riwayat Paparan Pestisida Ibu Saat Hamil Dengan Kejadian Stunting Anak Usia 2- 5 Tahun. 6, 24-31 (2018).

22. Suhartono. Dampak Pestisida terhadap Kesehatan. Pros. Semin. Nas. Pertan. Organik 15-23 (2014).

23. Malene Boas 1 , Ulla Feldt-Rasmussen 1, N. E. S. 1 and K. M. M. Environmental chemicals and thyroid function. Eur. J. Endocrinol. 154, 599611 (2006)

24. Wade, M. G. et al. Thyroid Toxicity Due to Subchronic Exposure to a Complex Mixture of 16 Organochlorines, Lead, and Cadmium. 218, 207-218 (2002).

25. Bianco, A. C. Biochemistry, Cellular and Molecular Biology, and Physiological Roles of the lodothyronine Selenodeiodinases. Endocr. Rev. 23, 38-89 (2002).

26. Solomon, D., Aderaw, Z. \& Tegegne, T. K. Minimum dietary diversity and associated factors among children aged $6-23$ months in Addis Ababa , Ethiopia. 1-9 (2017). doi:10.1186/s12939-017-0680-1

27. Saaka, M. How well do WHO complementary feeding indicators relate to nutritional status of children aged $6-23$ months in rural. BMC Public Health 1-12 (2015). doi:10.1186/s12889015-2494-7

28. Guerrant, Richard L, M. The impoverished guta triple burden of diarrhoea, stunting and chronic disease. Nat Rev Gastroenterol Hepatol 10, 220-229 (2013).

29. Cahyani, A. S. D. Hubungan Riwayat Pemberian Makanan Pendamping ASI (MP-ASI) dengan Persepsi Perilaku Picky Eater pada Anak Usia 12-36 Bulan (Studi di Wilayah Kerja Sidotopo Surabaya). Amerta Nutr. 3, 171 (2019).

30. Derso, T., Tariku, A., Biks, G. A. \& Wassie, M. M. Stunting, wasting and associated factors among children aged 6-24 months in Dabat health and demographic surveillance system site : A community based cross- sectional study in Ethiopia. 1-9 (2017). doi:10.1186/s12887017-0848-2

31. Lestari, W., Margawati, A. \& Rahfiludin, M. Z. 
Faktor risiko stunting pada anak umur 6-24 bulan di kecamatan Penanggalan kota Subulussalam provinsi Aceh. J. Gizi Indones. 3, 37-45 (2014).

32. Penelitian, A. H., Hafid, F. \& Gizi, S. Indonesian Journal of Human Nutrition. 3, 42-53 (2016).
33. Khasanah, D. P., Hadi, H. \& Paramashanti, B. A. Waktu pemberian makanan pendamping ASI ( MP-ASI ) berhubungan dengan kejadian stunting anak usia 6-23 bulan di Kecamatan Sedayu. (2016). 